\title{
ANALISA PELAKSANAAN KEGIATAN CUSTOMER GATHERING PT FOODY DIREKTORI INDONESIA
}

\author{
Angela Clarissa, Marcha Chryztantya, Vegys Gultom \\ London School of Public Relations, Jakarta, Indonesia \\ Angelaclarissa1996@gmail.com ${ }^{1}$;mrchryz97@gmail.com ${ }^{2}$; vegysg@gmail.com ${ }^{3}$
}

\begin{abstract}
One important part of an organization is external publics such as customers. Holding some events/activities by organization to their publics is often a necessary things to do. PT Foody Direktori Indonesia is a restaurant directory service company in Indonesia that holds customer gathering activities. This research focused on the implementation of customer gathering acitivites conducted by PT Foody Direktori Indonesia. The objective of this research is to see how the implementation of customer gathering and also to see the obstacles and efforts in the implementation of gathering. To analyze the gathering activities, this research use the concept from Dennis L. Wilcox of 8 stages public relations activities planning that contain situation, objectives, audience, strategy, tactics, calendar/timetable, budget, and evaluation. This research uses a qualitative method and interviews as the data collection technique. The result of this research is PT Foody Direktori Indonesia conducts their customer gathering activity according to the 8 stages of public relations activites planning by Dennis L. Wilcox. From this research it was also found that PT Foody Direktori Indonesia have some obstacles during planning gathering activities and already have made an effort to resolve these obstacles.
\end{abstract}

Keywords: Public Relations, Customer Relations, Customer Gathering

\begin{abstract}
Abstrak
Publik dalam sebuah perusahaan salah satunya adalah publik eksternal yaitu customer. Mengadakan sejumlah kegiatan dengan publik dari organisasi merupakan hal yang perlu dilakukan. PT Foody Direktori Indonesia merupakan salah satu perusahaan layanan direktori restoran yang mengadakan kegiatan customer gathering. Penelitian ini memiliki fokus pada pelaksanaan kegiatan customer gathering yang dilaksanakan oleh PT Foody Direktori Indonesia. Tujuan dari penelitian ini adalah untuk melihat bagaimana pelaksanaan dari kegiatan customer gathering dan juga untuk melihat hambatan dan upaya dalam pelaksanaan gathering. Untuk menganalisa kegiatan gathering tersebut, penelitian ini menggunakan konsep 8 tahap perancanaan kegiatan public relations menurut Dennis L. Wilcox yang berisi situation, objectives, audiences, strategy, tactics, calendar/timetable, budget dan evaluation. Metode penelitian ini adalah analisa kualitatif dengan menggunakan wawancara sebagai teknik pengumpulan data. Hasil penelitian menunjukan bahwa PT Foody Direktori Indonesia melaksanakan kegiatan customer gathering ini sesuai dengan 8 tahap perencanaan kegiatan public relations menurut Dennis L. Wilcox. Pada penelitian ini juga ditemukan bahwa PT Foody Direktori Indonesia mengalami sejumlah hambatan pada saat pelaksaan gathering dan sudah memiliki upaya dalam mengatasi hambatan tersebut.
\end{abstract}

Kata kunci : Public Relations, Customer Relations, Customer Gathering 


\section{PENDAHULUAN}

Kegiatan Public Relations kini menjadi salah satu kegiatan yang umum dilakukan dalam sebuah perusahaan tidak terkecuali oleh perusahaan startup. Adapun publik yang menjadi target dalam kegiatan tersebut terdiri dari publik internal maupun publik eksternal. Bentuk kegiatan yang dilakukan kini juga semakin beragam sesuai dengan kebutuhan dan juga bidang dari perusahaan/organisasi. Salah satu tujuan diadakannya kegiatan public relations adalah untuk dapat menjalin hubungan yang baik antara perusahaan/organisasi dengan publik yang mereka ingin berhubungan baik.

Kegiatan public relations menjadi salah satu kegiatan yang dapat dinilai penting bagi sebuah perusahaan/organisasi karena dapat menjadi sarana untuk menggali dan menyalurkan informasi penting antara organisasi dengan publiknya. Kegiatan ini juga dapat menjadi sebuah bentuk komunikasi yang dilakukan untuk mencapai tujuan dari sebuah organisasi. Di era modern ini, kegiatan public relations tidak hanya dilakukan oleh divisi public relations melainkan juga bisa dilaksanakan oleh divisi marketing.

Dalam perencanaan sebuah kegiatan public relations pastinya akan menggunakan perencanaan yang harus tepat agar sesuai dengan sasaran target. Maka dari itu dalam perencanaan kegiatan public relations dapat menggunakan beberapa tahapan penting, salah satunya adalah yang dikemukakan oleh Dennis L. Wilcox, Cameron, Ault dan Agee (2005, p. 148-158) yaitu situation, objectives, audience, strategy, tactics, calendar/time table, budgeting dan evaluation.

Perencanaan sebuah kegiatan public relations menjadi penting untuk mencapai tujuan organisasi, pada perencanaan tersebut akan dapat dirumuskan dengan lengkap apa yang menjadi kebutuhan organisasi dalam sebuah kegiatan public relations. Melalui tahapan perencanaan tersebut dapat menciptakan sejumlah bentuk kegiatan public relations yang kreatif dan inovatif.

Bentuk dari kegiatan public relations kini sudah semakin kreatif dan inovatif, salah satu kegiatan yang ditujukan untuk publik eksternal dari sebuah organisasi adalah customer relations. Publik eksternal dari sebuah organisasi yang kini dapat dikatakan cukup berpengaruh pada sebuah organisasi adalah customer, maka dari itu kegiatan customer relations dapat menjadi salah satu bentuk kegiatan yang akan membantu dalam pengembangan organisasi. 
Kegiatan customer relations sendiri memiliki orientasi yang ditujukan pada customer atau publik eksternal dari sebuah organisasi. Kegiatan ini masuk dalam kegiatan public relations dikarenakan menghubungkan antara publik internal dan publik eksternal dalam sebuah organisasi. Adapun bentuk kegiatan customer relations yang diteliti dalam penelitian ini adalah kegiatan customer gathering.

Kegiatan customer gathering sudah dilaksanakan oleh sejumlah organisasi, salah satunya adalah yang dilakukan oleh PT Foody Direktori Indonesia atau yang biasa disebut dengan Foody Indonesia. Ini juga dapat menjadi salah satu bentuk portofolio yang nantinya akan dimiliki oleh Foody Indonesia.

Foody Indonesia merupakan startup yang berada di bidang layanan direktori restaurant berbasis aplikasi yang berasal dari Vietnam. Foody masuk ke Indonesia sejak tahun 2015 dan sampai saat ini Foody Indonesia sudah berkembang di sejumlah kota di Indonesia seperti Jakarta, Bandung, Surabaya, Bali dan Jogjakarta. Dalam perkembangannya di Indonesia, Foody melakukan pendekatan dengan pengguna/customer mereka menggunakan kegiatan customer gathering. Sudah ada banyak kegiatan customer gathering yang berhasil dilaksanakan oleh Foody Indonesia.

Hingga bulan Juli 2018 kurang lebih sudah ada sekitar 300-an kegiatan customer gathering yang dilaksanakan oleh Foody Indonesia. Keberhasilan kegiatan customer gathering ini mendorong untuk melakukan penelitian yang berjudul Analisa Pelaksanaan Kegiatan Customer Gathering PT Foody Direktori Indonesia.

Adapun tujuan dilakukannya penelitian adalah untuk melihat bagaiamana pelaksanaan kegiatan customer gathering Foody Indonesia dan juga untuk melihat hambatan dan upaya yang dilakukan dalam pelaksanaan kegiatan customer gathering.

\section{Public Relations}

Menurut (British) Institute of Public Relations (IPR) (Jefkins \& Yadin, 2015, p. 9), public relations merupakan kegiatan yang menghasilkan sikap saling pengertian antara organisasi dengan publiknya dengan menggunakan kegiatan yang terencana dan berkesinambungan untuk memelihara hubungan baik.

Frank Jefkins (Jefkins \& Yadin, 2015, p. 10), public relations adalah semua aspek maupun bentuk kegiatan komunikasi yang sudah direncanakan, baik yang akan 
dilakukan ke dalam maupun keluar yang dilakukan dengan semua khalayak dalam organisasi guna mencapai tujuan-tujuan spesifik dengan asas saling pengertian.

Effendy (2009, p. 116) juga memberikan pernyataan yang sama dengan Cutlip dan Centre yaitu public relations adalah fungsi manajemen yang menilai sikap publik, mengidentifikasi kebijaksanaan dan tata cara seseorang atau organisasi demi kepentingan publik, serta merencanakan dan melakukan suatu program kegiatan untuk meraih pengertian dan dukungan publik.

\section{Fungsi Public Relations}

Menurut L.F. Urwick, fungsi hubungan atau relasi public (Public Relations) ini merupakan salah satu tugas manajeman Public Relations yang utama dalam perusahaan, yaitu untuk melaksanakan:

1) Mendengarkan pendapat dan aspirasi public serta mengidentifikasi keinginan publik dan khalayak sasarannya;

2). Menyampaikan sumbang-saran dan ide atau gagasan kreatif kepada pimpinan organisasi demi manfaat bersama bagi perusahaan dan public;

3). Mampu menciptakan suasana iklim yang kondusif dan hubungan yang harmonis serta positif untuk kalangan internal dalam membangun hubungan baik bagi kedua belah pihak. (Ruslan, 2016 p.32 \& 33)

\section{Kegiatan Public Relations}

Untuk menjalankan fungsi dari Public Relations, biasanya divisi terkait akan merencanakan sebuah kegiatan yang menjadi media dalam menyampaikan pesan maupun untuk menjaga hubungan baik dengan publiknya. Kegiatan Public Relations dibedakan menjadi dua yaitu internal dan eksternal. Kegiatan internal, biasanya yang dilakukan adalah employee relations, labour relations dan stakeholder relations. Sementara untuk kegiatan eksternal yaitu customer relations, supplier relations, community relations, goverment relations dan press relations (Abdurrachman, 2001 p. 34 \& 38)

Pada penelitian ini, salah satu jenis kegiatan yang dilakukan oleh PT. Foody Direktori Indonesia dengan publik eksternalnya yaitu melakukan kegiatan customer relations dalam bentuk customer gathering.

\section{Perencanaan Kegiatan Public Relations}

Menurut Wilcox, Cameron, Ault dan Agee (2005, p. 148-158) terdapat 8 element perencanaan kegiatan public relations diantaranya adalah:

\section{Situation}

Situasi menjelaskan 3 aspek penting 
diantaranya harus menjelaskan mengenai sebuah organisasi harus membuat program perbaikan dalam mengatasi sebuah masalah tertentu, sebuah organisasi harus melaksanakan sebuah program dalam waktu tertentu dan organisasi dapat memperkuat citra di mata publik.

\section{Objective}

Tujuan dari sebuah kegiatan public relations dapat dibagi menjadi dua yaitu tujuan informasi yang menjelaskan mengenai sebuah kegiatan akan menjelaskan sebuah ekspos dan publikasi informasi kepada publik. Kedua adalah tujuan motivasi yang menjelaskan mengenai sebuah tujuan yang dapat diukur dengan angka tertentu.

\section{Audience}

Sebuah program public relations harus ditujukan kepada khalayak yang pasti dan spesifik, selain itu juga harus bisa menjelaskan key publics berdasarkan demografi.

\section{Strategy}

Strategi mendeskripsikan bagaimana dalam sebuah konsep, sebuah tujuan harus dicapai, dapat memberikan tema dan panduan untuk keseluruhan program. Unsur strategi dari sebuah perencanaan program harus menyebutkan tema dan pesan utama yang akan disampaikan pada semua program dan materi publikasi.

\section{Tactics}

Menjelaskan mengenai kegiatan spesifik yang memasukan strategi ke dalam sebuah perencanaan dan membantu dalam mencapai tujuan yang sudah ditetapkan. Taktik ini akan melibatkan penggunaan alat komunikasi untuk menjangkau khalayak primer dan sekunder dengan sebuah pesan utama.

\section{Calendar/Time Table}

Dalam perencanaan sebuah kegiatan harus menjelaskan 3 aspek diantaranya memutuskan kapan sebuah program harus dijalankan, menentukan urutan aktivitas yang benar dan menyusun daftar langkahlangkah yang harus dikerjakan dalam menyelesaikan program.

\section{Budget}

Di dalam sebuah perencanaan program public relations pastinya akan selalu ada anggaran biaya. Tidak ada program yang berhasil tanpa anggaran biaya. Pada perencanaan biaya, Organisasi akan menetapkan jumlah yang mereka mampu lalu staf public relations akan membuat anggaran yang sesuai. Anggaran dalam perencanaan program public relations biasanya akan menyesuaikan berdasarkan pengalaman atau berdasarkan permintaan dari vendor. 
Evaluation

Elemen dari evaluasi ini akan berhubungan langsung dengan tujuan yang sudah ditetapkan. Kriteria dari sebuah evaluasi harus realistis, spesifik dan sesuai dengan harapan.

\section{Customer Relations}

Nolte (2016, p. 213, 224) dalam buku Fundamental of Public Relations: Professionals Guidelines, Concepts and Integrations mengatakan:

"Relations with customers are often as much a marketing problem as a public relations problem. This may be an effort to euphemize because customers are publics, and customer relations is a public relations function."

Berbeda dengan Roger Cartwright dalam buku Customer Relationships (Cartwright, 2003 p. 8 \& 9) yang mendefinisikan Customer Relations sebagai berikut:

"Customer Relations is more than just that providing excellent care and service at the point of transaction. This relationship also need effort to establishing them and there are vital maintenance functions. Good customer relations goes beyond satisfying the customer's needs as it also delights the customer in terms of wants."
Berdasarkan penjelasan customer relations dari kedua ahli diatas, dapat disimpulkan bahwa customer relations merupakan kegiatan yang dilakukan oleh organisasi dalam rangka menjalin hubungan baik antara customer dan organisasi, pada kegiatan customer relations ini juga bisa menjadi ajang untuk organisasi dan customer saling bertukar pikiran untuk perkembangan organisasi. Sebuah organisasi atau perusahaan harus selalu menjalin hubungan yang baik juga agar citra organisasi tersebut tidak akan menurun di mata masyarakat atau publiknya. PT. Foody Direktori Indonesia kerap kali mengadakan kegiatan customer gathering yang menjadi salah satu bentuk dari customer relations yang diadakan perusahaan.

\section{Tujuan Customer Relations}

Nolte (2016, p. 219) dalam buku Fundamental of Public Relations: Professionals Guidelines, Concepts and Integrations mengatakan:

"The primary objectives in a customer relations program is to help make a sales because customer relations is secondary to sales function. It is not possible to have a customer relations program unless there are customer"

Berdasarkan uraian diatas, dapat dikatakan salah satu tujuan utama dari 
kegiatan customer relations adalah untuk mencapai kepuasan dari pelanggan. Nantinya dari kepuasan inilah pelanggan akan terus loyal kepada perusahaan atau organisasi dan dapat menjadikan citra perusahaan baik. Hal ini juga dapat terjadi pada PT. Foody Direktori Indonesia yang mengadakan kegiatan customer gathering yang dapat menjadikan customer loyal dan selalu menggunakan aplikasi Foody.

\section{METODOLOGI PENELITIAN}

\section{Desain Penelitian}

Penelitian ini menggunakan metode penelitian kualitatif. Menurut Raco (2010), Metode kualitatif adalah mencari pengertian yang mendalam tentang suatu gejala, fakta atau realita. Hasil penelitian kualitatif sangat dipengaruhi oleh pandangan, pemikiran, dan pengetahuan peneliti.

\section{Lokasi dan Jadwal Penelitian}

Lokasi penelitian dilakukan di PT Foody Direktori Indonesia dengan kantor pusat yang berada di Jakarta. Kantor pusat ini berada di Wisma 77 Tower 2, Lt. 11, Jl. Letjen S. Parman Kav.77, Slipi, Jakarta Barat.

\section{Subjek dan Objek Penelitian}

Pemilihan narasumber sebagai subjek penelitian telah dipilih berdasarkan keterkaitan dengan penelitian. Narasumber dalam penelitian ini adalah empat orang pihak internal PT Foody Direktori Indonesia, yang terdiri dari Team Leader, Head of Content, Community and Partnership Manager, dan Head of Sales. Sementara dari pihak eksternal yaitu customer (peserta gathering).

Sedangkan objek dalam penelitian ini adalah pelaksanaan kegiatan customer gathering PT. Foody Direktori Indonesia.

\section{Jenis dan Sumber Data \\ Data Primer}

Data primer ialah data asli yang dikumpulkan sendiri oleh peneliti yang berarti utama langsung dari sumbernya, data ini akan membantu menjawab masalah penelitiannya secara khusus. Peneliti harus melakukan pengumpulan data sendiri karena data ini tidak tersedia sebelumnya. (Istijanto, 2005 p. 32).

Pada penelitian ini, peneliti menggunakan 3 teknik pengumpulan data yaitu:

1). Wawancara mendalam dengan key informan atau responden guna menggali informasi detail.

2). Dokumentasi dengan menggunakan data-data berupa gambar, foto dan artikel. Bahan dokumentasi ini akan menjadi salah satu referensi lain untuk mengumpulkan data dalam penelitian. 
3). Observasi Lapangan

Pada teknik ini, peneliti akan secara langsung mengamati kegiatan customer gathering yang akan diadakan pada bulan Febuari/Maret.

\section{Data Sekunder}

Menurut Istijanto (2005), Data sekunder adalah data yang sudah dikumpulkan oleh peneliti lain sebelumnya. Data ini tidak dipengaruhi oleh penelitian yang sedang dijalankan oleh peneliti sebab data ini sudah disediakan oleh pihak lain pada waktu tertentu. Pada penelitian ini data sekunder yang digunakan adalah buku, jurnal dan bacaan yang membantu melengkapi penelitian ini.

\section{Teknik Pengumpulan Data}

\section{Interview}

Dalam mengumpulkan data yang berguna untuk pengembangan penelitian, peneliti disini menggunakan teknik interview atau wawancara. Adapun narasumber yang menjadi sumber informasi antara lain:

a. Sherly, Community and Partnership PT Foody Direktori Indonesia;

b. Justian Edwin, Head of Content PT Foody Direktori Indonesia; c. Hendi Pratama, Head of Sales PT Foody Direktori Indonesia;

d. Peserta Gathering.

\section{Dokumentasi}

Teknik pengumpulan data yang selanjutnya adalah melalui dokumentasi. Pada penelitian ini peneliti menggunakan data-data pendukung yang berasal dari buku dan juga media sosial Foody Indonesia.

\section{Teknik Analisis Data}

Teknik analisis data yang digunakan dalam penelitian ini adalah menggunakan teknik analisa data dari model Miles and Huberman. Terdapat tiga jenis analisa data yang dikemukakan oleh Miles and Huberman antara lain:

1). Reduksi, merupakan suatu bentuk analisis yang mempertajam, memilih, memfokuskan, membuang, menyusun data dalam suatu cara dimana kesimpulan akhir dapat digambarkan.

2). Model data (data display), merupakan suatu kumpulan informasi tersusun yang membolehkan pendeskripsian kesimpulan dan pengambilan tindakan, biasanya yang digunakan adalah teks naratif.

3). Penarikan/Verifikasi kesimpulan, permulaan pengumpulan data, peneliti kualitatif mulai memutuskan apakah makna sesuatu, mencatat keteraturan, 
pola-pola, penjelasan, konfirgurasi yang mungkin, alur sebab-akibat, dan proposisiproposisi (Ardianto, 2011 p. 223)

\section{Teknik Pemeriksaan Kepercayaan}

Pada penelitian ini, untuk mengecek keabsahan data menggunakan triangulasi sumber. Menurut Pawito (2007), Triangulasi dengan sumber berfokus pada upaya peneliti untuk mengakses sumbersumber yang lebih bervariasi untuk memperoleh data berkenaan dengan persoalan yang sama. Hal ini berarti peneliti bermaksud menguji data yang diperoleh dari satu sumber dengan sumber lain. Dari sini peneliti akan menemukan satu kemungkinan yaitu konsisten, tidak konsisten atau berlawanan.

Melalui metode triangulasi sumber, peneliti menguji keabsahan data yang diperoleh dari hasil wawancara para narasumber.

\section{HASIL DAN PEMBAHASAN}

Pada bagian ini peneliti akan menjelaskan mengenai hasil yang di dapatkan dari wawancara dan pengamatan dokumentasi yang dilakukan langsung dalam pengamatan pelaksanaan kegiatan customer gathering yang dilaksanakan oleh PT Foody Direktori Indonesia. Pada bagian ini, peneliti akan menjelaskan mengenai bagaimana pelaksanaan kegiatan customer gathering tersebut berdasarkan delapan elemen perencanaan kegiatan public relations yang dikemukakan oleh Dennis L. Wilcox, selanjutnya peneliti akan menjelaskan mengenai hambatan apa saja yang terjadi dalam kegiatan customer gathering dan terakhir peneliti akan menjelaskan mengenai upaya yang dilakukan untuk mengatasi hambatan yang terjadi dalam pelaksanaan customer gathering.

\section{Pelaksanaan Kegiatan Customer Gathering PT Foody Direktori Indonesia}

Untuk melaksanakan sebuah kegiatan customer gathering Foody Indonesia akan membutuhkan perencanaan kegiatan yang tepat. Pada konteks ini, peneliti menggunakan konsep perencanaan kegiatan public relations dari Dennis L. Wilcox dalam melakukan analisa terhadap perencanaan yang dilakukan oleh Food Indonesia. Berikut ini adalah hasil yang ditemukan sesuai dengan delapan elemen yang digunakan antara lain:

\section{Situation}

Untuk menemukan hasil yang tepat, situasi dibagi kembali menjadi 3 aspek yaitu waktu, mempertahankan citra dan S.W.O.T. 
Pada konteks analisa situasi waktu, Foody Indonesia melaksanakan kegiatan customer gathering untuk merayakan sejumlah moment-moment tertentu. Hal ini sesuai dengan konsep yang dijelaskan oleh Wilcox dimana sebuah organisasi harus melaksanakan kegiatan dalam waktu tertentu.

Pada konteks kedua yaitu mempertahankan citra. Foody Indonesia mengatakan bahwa kini kegiatan customer gathering masuk sebagai sebuah sales package yang menjadi portofolio untuk sejumlah calon client. Hal ini tentu saja sesuai dengan konteks mempertahankan citra dimana kegiatan customer gathering yang sukses dapat memberikan citra positif untuk Foody Indonesia.

Konteks terakhir adalah S.W.O.T, pada konteks ini dijelaskan mengenai hal-hal penting yang dapat mempengaruhi situasi dalam perencanaan kegiatan customer gathering Foody Indonesia.

Objective

Pada konteks objective (tujuan) ini dibedakan menjadi dua yaitu informational objective dan motivational objective. Keduanya memiliki perbedaan dalam pengukuran keberhasilan dari pelaksanaan sebuah kegiatan public relations.
Pertama adalah informational objective yang menjelaskan mengenai sebuah kegiatan harus dapat menjelaskan ke publik mengenai informasi untuk meningkatkan perhatian publik. Tujuan ini juga lebih mengarah kepada tujuan yang umum. Menurut Wilcox juga tujuan ini harus dapat membantu dalam meningkatkan awareness dari publik. Foody Indonesia menjadikan kegiatan customer gathering ini sebagai sarana untuk mengenalkan Foody Indonesia kepada khalayak luas terutama untuk mereka yang belum pernah mengenal layanan direktori restaurant sebelumnya. Hal ini tentu saja sesuai dengan informational objective yang dikemukakan oleh Dennis L. Wilcox.

Kedua, motivational objective menjelaskan mengenai sesuatu yang dapat diukur atau dihitung, pada konteks ini dapat dihubungkan juga dengan angka peningkatan penjualan ataupun awareness. Foody Indonesia memiliki KPI (Key Point Indicator) yang dapat menjadi motivational objective dalam pelaksanaan kegiatan customer gathering.

\section{Audience}

Pada konteks audience (publik) dibagi menjadi tiga yaitu segmentation, targeting dan positioning. 
Pertama adalah segmentation, Foody Indonesia dalam melaksanakan kegiatan customer gathering pastinya memiliki segmentasi publik yang dimana dibedakan berdasarkan jenis kelamin, usia dan lokasi. Kedua adalah targeting, pada konteks ini Foody Indonesia memiliki 2 target peserta yang dibedakan berdasarkan tipe acara yang dilaksanakan yaitu acara dari divisi sales atau dari divisi marketing. Untuk acara yang dilaksanakan oleh divisi sales target yang dimiliki adalah food blogger. Sementara untuk kegiatan yang dilaksanakan oleh divisi marketing target peserta yang dimiliki adalah beberapa dari food blogger dan sisanya adalah pengikut Foody Indonesia.

Ketiga adalah positioning, merupakan hal yang dilakukan untuk menempatkan tempat khusus pada benak publik yang menjadi target. Pada konteks ini Foody Indonesia ingin memperkenalkan pada publik bahwa ada culinary app yang dinamakan Foody Indonesia dan ingin memasangkan pemikiran di benak publik bahwa jika ingin melakukan review makanan dapat dilakukan di Foody Indonesia.

\section{Strategy}

Konteks strategy ini dibedakan menjadi tiga yaitu konsep, tema dan publikasi.
Pertama, konsep yang digunakan Foody Indonesia dalam kegiatan customer relations yang diadakan adalah gathering. Sementara itu untuk konsep acara juga akan menyesuaikan dengan tema yang akan digunakan.

Kedua adalah tema. Foody Indonesia selalu menggunakan tema yang berbedabeda disesuaikan dengan bulan atau moment yang terjadi. Tema juga menjadi panduan dalam seluruh rangkaian kegiatan, hal ini sesuai dengan yang dikemukakan oleh Dennis L. Wilcox. Berdasarkan tema yang sudah disesuaikan nantinya pihak Foody Indonesia dapat menentukan jenis kegiatan apa yang akan dilakukan selama gathering.

Terakhir adalah publikasi, setiap kegiatan pastinya akan membutuhkan publikasi yang dimana harus menyebutkan tema dan pesan yang akan disampaikan. Pihak Foody Indonesia dalam konteks ini menggunakan social media sebagai media publikasi acara gathering.

\section{Tactics}

Konteks tactics merupakan penjelasan lebih lengkap dari strategy, dibagi kembali menjadi tiga bagian yaitu konsep, tema dan publikasi.

Pertama adalah konsep, kegiatan gathering yang diadakan oleh Foody Indonesia dibagi menjadi dua yaitu taste 
food dan general gathering. Perbedaan konsep ini dapat terlihat dari divisi yang menyelenggarakan gathering, taste food merupakan kegiatan yang dilaksanakan oleh divisi sales, sementara itu untuk kegiatan general gathering merupakan kegiatan dari divisi marketing. Adanya kedua jenis konsep kegiatan tersebut menunjukan bahwa Foody Indonesia memiliki perencanaan yang tepat karena acara gathering disesuaikan dengan kebutuhan masing-masing divisi.

Kedua adalah tema, setiap kegiatan gathering akan memiliki tema yang berbeda-beda disesuaikan dengan bulan atau moment yang terjadi. Hal ini juga disampaikan oleh pihak Foody Indonesia dimana mereka mengadakan kegiatan gathering disesuaikan dengan moment setiap bulannya seperti Christmas atau Valentine.

Terakhir adalah publikasi, pada saat melakukan publikasi mengenai kegiatan gathering, Foody Indonesia menggunakan media sosial atau menggunakan undangan langsung kepada pihak yang akan diundang menggunakan Whatsapp. Berdasarkan pernyataan tersebut juga dapat dikatakan bahwa pihak Foody Indonesia menggunakan alat komunikasi yang tepat dalam menjangkau peserta gathering.

\section{Calendar/Time Table}

Konteks pada bagian calendar/time table ini dibagi menjadi dua yaitu waktu kegiatan dan langkah-langkah perencanaan.

Pertama adalah waktu kegiatan, Foody Indonesia memiliki perencanaan waktu yang tepat karena setiap awal tahun kegiatan gathering sudah direncanakan yaitu pembuatan perencanaan 3 bulan sekali. Hal ini sesuai dengan pernyataan dari Wilcox dimana sebuah kegiatan harus direncanakan dalam kurun waktu tertentu.

Kedua adalah langkah-langkah perencanaan, , dalam merencanakan kegiatan gathering Foody Indonesia juga menggunakan meeting dengan pihak restoran yang akan menjadi client. Meeting ini menjadi bagian dari langkah-langkah perencanaan kegiatan yang dilakuakn Foody Indonesia.

\section{Budgeting}

Pada kegiatan gathering, Foody Indonesia juga menggunakan budgeting sebagai bagian dari perencanaan kegiatan. Pada kegiatan ini budgeting yang digunakan akan di sesuaikan dengan kebutuhan client dan biasanya setiap acara memiliki budgeting yang berbeda-beda.

\section{Evaluation}

Konteks evaluasi dalam sebuah perencanaan kegiatan ini harus sesuai 
dengan tujuan awal yang dimiliki oleh perencana kegiatan. Sebuah evaluasi juga harus realistic, spesifik dan sesuai dengan harapan.

Pada kegiatan customer gathering, Foody Indonesia menggunakan evaluasi dalam bentuk KPI (Key Point Indicator) untuk menentukan keberhasilan dari kegiatan gathering yang diadakan. KPI yang dimiliki oleh Foody Indonesia berisi mengenai insight yang di dapatkan dari acara yang diselenggarakan dan juga kehadiran peserta acara yang diselenggarakan.

\section{Hambatan-hambatan}

Dalam penyelenggaraan dan juga perencanaan kegiatan customer gathering tidak semuanya mulus sesuai dengan perencanaan yang dilakukan. Terdapat sejumlah hambatan-hambatan yang dihadapai Pihak Foody Indonesia antara lain:

\section{Audience}

Pada saat melakukan gathering terdapat hambatan dalam jumlah kehadiran peserta. Hambatan yang terjadi pada tahap audience ini adalah jumlah peserta yang hadir sering kali melebihi kuota peserta yang disediakan.

\section{Strategy}

Hambatan yang terjadi pada tahapan strategy adalah adanya kesulitan dalam menentukan tema yang sesuai dengan kegiatan. Menurut pihak Foody mereka sering kali kesulitan dalam menentukan tema di bulan-bulan yang tidak terdapat moment atau perayaan tertentu.

\section{Calendar}

Hambatan juga terjadi pada elemen calendar atau yang biasa disebut juga time table. Pihak Foody Indonesia merasakan hambatan pada saat mencocokan jadwal antara peserta gathering dengan pihak restoran. Hambatan ini juga yang menjadi fokus utama kini dalam melakukan mencocokan jadwal kegiatan gathering.

\section{Budgeting}

Hambatan yang dihadapi oleh pihak Foody Indonesia dalam elemen budgeting adalah terbatasnya pendanaan yang diberikan oleh para client. Budget juga dapat mempengaruhi kegiatan yang dilakukan oleh Foody Indonesia.

\section{Upaya-upaya}

Melihat adanya hambatan-hambatan yang dihadapi oleh Foody Indonesia, tentu saja ada upaya yang dilakukan untuk mengatasi hambatan tersebut. Berikut ini adalah upaya yang dilakukan antara lain:

\section{Audience}

Upaya yang dilakukan untuk
mengatasi hambatan yang berupa
kehadiran peserta yang melebihi kuota
adalah pihak Foody Indonesia akan


melakukan negosiasi ke pihak restaurant. Negosiasi ini dilakukan untuk terus menjaga keberlangsungan kegiatan gathering sehingga dapat berjalan sampai dengan selesai.

\section{Strategy}

Pihak Foody Indonesia merasakan hambatan pada saat menentukan tema acara kegiatan gathering. Untuk mengatasi hambatan tersebut maka upaya yang dilakukan oleh Foody Indonesia adalah dengan mencari alternative tema berdasarkan sesuatu hal yang sedang banyak dibicarakan oleh sejumlah kalangan. Biasanya tema-tema tersebut juga dapat muncul dari viral-nya pemberitaan.

\section{Calendar}

Hambatan yang ditemukan oleh Foody Indonesia dalam elemen calendar adalah adanya kesuliatan dalam pencocokan jadwal antara peserta dengan pihak restaurant. Maka dari itu untuk mengatasi hambatan tersebut maka ada upaya yang dilakukan berupa mencari alternative peserta lain yang dapat menghadiri acara gathering. Pihak Foody Indonesia juga akan menghubungi food blogger yang lainnya untuk menjadi peserta cadangan.

\section{Budgeting}

Hambatan yang dihadapi oleh Foody Indonesia adalah adanya keterbatasan budget yang biasanya dimiliki oleh client atau pihak restaurant dalam mengadakan kegiatan gathering. Upaya yang dilakukan oleh Foody Indonesia dalam mengatasi hambatan tersebut adalah mereka melakukan barter dengan pihak restaurant, contoh adalah Foody Indonesia memberikan gratis promosi dilakukan di sosial media Foody, nantinya pihak restaurant akan menambahkan service mereka.

\section{PENUTUP}

Berdasarkan hasil wawancara dengan pihak terkait serta hasil analisis maka aktivitas customer gathering yang dilaksanakan oleh PT Foody Direktori Indonesia sudah sesuai dengan delapan elemen perencanaan kegiatan public relations yang disampaikan oleh Dennis L. Wilcox.

Adapun dari perencanaan ini juga, Foody Indonesia menghadapi sejumlah hambatan, namun Foody Indonesia berhasil mengatasi hambatan-hambatan tersebut sehingga acara gathering dapat berjalan dengan lancar. 
DAFTAR PUSTAKA

Abdurrachman, O. (2001). Dasar-dasar Public Relations. Bandung: PT Citra Aditya Bakti.

Ardianto, D. D. (2011). Metodologi Penelitian untuk Public RelationsKualitatif \& Kuantitatif. Bandung: Simbiosa Rekatama Media.

Cartwright, R. (2003). Customer Relationships. United Kingdom: Capstone Publishing

Effendy, O. U. (2009). Human Relations dan Public Relations. Bandung: Penerbit Mandar Maju.

Istijanto. (2005). Riset Sumber Daya Manusia. Jakarta: PT Gramedia Pustaka Utama.
Jefkins, F., \& Yadin, D. (2015). Public Relations (Kelima ed.). Jakarta: PT Erlangga. Nolte, Lawrence W. (2016), Fundamental of Public Relations: Professionals Guidelines, Concepts and Integration. United States of America: Elsevier.

Ruslan, R. (2016). Manajemen Public Relations dan Media Komunikasi, Konsepsi dan Aplikasi (13 ed.). Jakarta: PT Raja Grafindo Persada.

Raco, D. J. (2010). Metode Penelitian Kualitatif. Jakarta: Grasindo.

Wilcox, D. L., Cameron, G. T., Ault, P. H., \& Agee, W. K. (2005). Public Relations Strategies and Tactics (7th ed.). Boston: Allyn \& Bacon. 